\title{
Searching for Zion: Pan-African Feminist Thought and Practice in English-speaking Black Montreal (1967-1977)
}

\author{
Amanda Ricci, McGill University
}

Scholars and observers have commonly portrayed the 1960s and 1970s as decades of intense political activity. In Montreal, the Québec neo-nationalist movement, the women's liberation movement and the "Black Renaissance" exemplified the heightened atmosphere of contestation reigning in the city. ${ }^{1}$ How did Montreal's English-speaking African Canadian women fit into this matrix of activism, specifically the resurgence of feminist activism in the 1960s and 1970s? The answer lies outside traditional analyses of the "second-wave" feminist movement where only autonomous women's organisations have been studied. As we will see, black women were involved in multiple political groups during this period, from black women's organisations, to male-dominated black groups, to mixed-raced, women-only settings. ${ }^{2}$ By drawing upon the work of critical race and feminist scholars, this article also argues for the importance of transnational analyses in understanding the multi-faceted nature of black women's political activity. ${ }^{3}$ Because of their connections with other activists around the world, Montreal's African Canadian women's activism not only challenges many of the ways that we have come to understand the "second-wave" feminist movement, but also typical narratives of Canadian nationhood.

This article is thus inscribed in the tradition of looking at the competing feminist nationalisms in Canada. ${ }^{4}$ Montreal's African Canadian women's activism was informed by their positionality within multiple nations: the Canadian and Québec nations (but more so Canadian because they were English-speaking), the Caribbean nations many had left behind, as well as the diasporic Pan-African nation, defined as the international community of black peoples. Further underlining the polyvocal character of Montreal society, this article will concentrate nearly exclusively on the Anglophone black community, since Haitian women had their own distinct brand of 1970s activism. ${ }^{5}$ More specifically, it will focus on women born in the English-speaking Caribbean and, in particular, on the important role played by Dorothy Wills, a community leader whose activism reflected the political consciousness of the period. Due to the complexity stemming from the multiple, overlapping national imaginaries present in Canada, this article represents a preliminary attempt at discerning the relationship between feminism, Pan-Africanism, and unequal access to political resources in Québec's metropolis, itself a highly contested site.

While the boundaries delineating "insiders" and "outsiders" are porous in nationalist discourses across geopolitical spaces, in Canada during the period 
of study, the definition of the nation was particularly in flux. The push towards self-determination on the part of Francophone Quebecers and First Nations, as well as the claims for full citizenship rights by ethnocultural and "visible" minorities challenged the notion of "Anglo conformity" and set the stage for passionate debate. Women from a range of communities were invested in this discussion and used nationalism to both advance and critique their socio-economic position. The Front de libération des femmes, established in 1969, best represented the mutually constitutive power of feminism and nationalism with its mantra: "No liberation of women without the liberation of Québec! No liberation of Québec without the liberation of women!" Yet very little historical research has been conducted with regard to immigrant and ethnic minority women's attachment to their respective "imagined communities." By analyzing the relationship between feminism and Pan-Africanism, this article explores the positionality of these ideologies in relation to English- and French-Canadian women's activism and, by extension, Anglophone black women's rapport vis-à-vis their receiving society and community of origin. ${ }^{6}$ As residents of Québec, where the "nation" was most obviously in the process of redefinition, Montreal's black feminists were perhaps even more willing to put forth their own claims, relying upon a variety of frameworks, especially those embraced by African descended peoples.

As David Austin points out in his article, "All Roads Led to Montreal," Canada had its own version of Black Power, which "like so many social movements around the world in the 1960s and 1970s, drew inspiration from African American struggles against economic and racial oppression, but [was] nonetheless native to Canada." 7 With approximately $80 \%$ of Montreal's African Canadians born in the Caribbean as of 1968, the community's activism was intrinsically transnational, drawing inspiration from the intertwined ideologies of Pan-Africanism and Black Power. During this time of heightened contestation, some black Montrealers, but of course not all, re-imagined themselves as part of the global community, making links with other black collectivities in the United States, Caribbean, and Africa, reconfigured as the "Motherland." Though born out of the legacy of slavery, Diaspora politics were also the lens through which African descended peoples worldwide chose to assert their cultural specificity, appropriating, for example, African spirituality or dress. The Jamaican-born Marcus Garvey, known as the "Black Moses," provided the initial impetus towards the idealized return to Africa in the form of "Black Zionism." The sentiment then crystallized in W.E.B. Du Bois' concept of "double-consciousness," defined as the unhappy synthesis of racially particularistic thinking within the framework of the nation-state, with a diasporic way of seeing the ways in which black communities everywhere were subjected to racism. ${ }^{8}$

On the organisational level, the Universal Negro Improvement Association (UNIA) was the first to express an internationalist approach to 
resistance, espousing a "back-to-Africa" rhetoric. Founded by Garvey in the early $20^{\text {th }}$ century and established in Montreal in 1919, the organisation's inherently diasporic philosophy laid the groundwork for the radical Pan-Africanism of the late 1960s and 1970s. Whereas West Indian immigrants and women formed the backbone of the UNIA at the turn of the century, they also played an important role during the "long black Sixties," when "a common language of black liberation gained worldwide prominence and currency." So once the demographics of Montreal's diverse black community shifted in favour of the foreign-born during this period, community leaders were able to tap into porous and flexible Black Power ideologies. They evoked similar experiences with discrimination in order to unify a disparate group of people, as well as reach out to other Diaspora centres. Dorothy Wills' approach to combating socio-economic inequalities combining Pan-Africanism and anti-racism, exemplified these tendencies. Dominica-born, the activist led, in Charmaine Nelson's words, a "doubly diasporized" life, in that, with cultural origins in the Caribbean, Wills also experienced the heterogeneity of Black Canada; "two former sites of empire." 10 Like other community leaders, then, Wills had to negotiate the creative tension between "local experience and diasporic consciousness." 11 The international networks fostered between black communities, in North America, the Caribbean and Africa, shaped this process. By reflecting on the dynamic between the African Diaspora and the Montreal community, this article therefore hopes to contribute to the burgeoning scholarship on diasporic conceptions of Canadian and Montreal blackness, paying close attention to gender differences. ${ }^{12}$

As we will see, the Pan-Africanist discourses expressed by Montreal's African Canadian women, equally passionate as men's, nevertheless demonstrated the difficulty in carving out a place for women within this form of Black Nationalism. Although adhering to an ideology which sometimes promoted a subordinate, child-raising role for women, women activists to varying degrees refused to view their contribution to the black struggle solely in terms of revolutionary motherhood, taking on leadership positions within the movement. Starting off within the Caribbean Conference Committee and the Negro Citizenship Association, Anne Cools and Dorothy Wills, for example, later became involved in feminist initiatives such as the Congress of Black Women. As the latter organisation would indicate, black women founded their own autonomous organisations, because, in addition to a highly masculinity Black Power movement, they had to negotiate the pervasive whiteness present within the women's movement. Furthermore, Euro-Canadian women tended to have understandings of patriarchy, the family, and reproduction incompatible with the lives of African Canadian women, who were subjected to both racial discrimination and sexism. For black women, socio-economic and political divergences amongst women led to another strand of feminism, and even an alternative 
understanding of citizenship, one that took into consideration the limitations of being both black and female in the Canadian context, in this case, Montreal.

\section{Laying the Foundation}

According to the historian Dorothy Williams, the author of The Road to Now: a History of Blacks in Montreal, "To understand black women and their history we cannot only compare them to other women - they must be placed in the context of their families, their black sisterhood and especially their communities." Although the historical record has been relatively silent with regard to the contributions of Black Montrealers and African Canadian women more generally, African descended women have deep roots in Québec and an equally longstanding reputation for resistance to economic inequality and racial oppression. ${ }^{13}$ For instance, the Coloured Women's Club of Montreal (CWC) had been dedicated to the well-being of Montreal's black collectivity "in every possible way" since its inception in 1902, providing moral guidance, emotional support, a sense of belonging, and in some cases, food and clothing. The CWC's membership was often involved in more than one community organisation, extending its energies to the Union Congregational Church and the Negro Community Centre, founded in 1907 and 1927 respectively. In fact, the collectivity's institutional network as a whole during this period could not have existed without the strong and commanding presence of women, who were the bulk of the volunteers and served as staff members. Founded in reaction to the racially-exclusionary, Anglo-Saxon suffragette groups, the CWC's focus on the socio-economic issues facing the black community created the framework for African Canadian women's political experience and social involvement. ${ }^{14}$ The same held true for the period leading up to and surrounding the resurgence in feminist activism. These years also coincided with a new immigration wave and the parallel, but interrelated rise of a reinvigorated "black internationalism."15

Although coming out of decades of struggle and community organising, Montreal's black community's activism in the late 1960s and 1970s was nonetheless indicative of a radical change in self-conception. As stated in the February 1971 edition of the Black Scholar, an American magazine with a continent-wide readership, Pan-Africanism was re-emerging as "the dominant political thrust of Africans in this country." 16 The same could be said for English-speaking black peoples in Canada. One such African Canadian was Dorothy Wills, well-known for her work within the Negro Citizenship Association, and later for the National Black Coalition and the Congress of Black Women. A teacher by profession, Wills dedicated her free time to the community, becoming heavily involved in the global Pan-Africanist movement, even adopting the name Abike after a visit to Africa in $1971 .{ }^{17}$ Born in the Dominica on March $13^{\text {th }}, 1933$, this 
community leader immigrated to Canada in the early 1950s to attend Mount Saint Vincent University. She then made her way to McGill University to complete a degree in social work, before obtaining a doctorate in the philosophy of education. In Montreal, she met her Nigerian-born husband and settled down to raise a family and work at Vanier College. ${ }^{18}$ With The Black Scholar on her bookshelf, alongside the works of the major Black Nationalist and anti-colonial thinkers of the day, Dorothy Wills' intellectual endeavours and political persuasions, as we will see, were indicative of the rejuvenated political consciousness and organisational tactics of the period. ${ }^{19}$

Like the community as a whole, Wills' activism did not start in the 1970s. Rather, the community leader's quest for equality can be traced back to her work within the Negro Citizenship Association, starting in the 1950s. As its name would indicate, the Association was a civil rights organisation, promoting anti-discrimination legislation. Founded in 1952, the group consisted of 400 members, born in Canada, the United States, the West Indies, and Africa. The organisation's motto, "Dedicated to the Principles of Good Citizenship," was interpreted as pushing Canadian society to uphold at home the objectives they supported on the world stage, outlined in, for example, the United Nations Declaration of Human Rights. ${ }^{20}$ Two prominent battles waged by the organisation's members included the integration of the taxi industry in 1960 and an amendment to the Hotels Act in 1963, making it illegal to refuse service to a customer because of his or her race. ${ }^{21}$ As for Dorothy Wills, her gender did not seem to impede involvement in this civil rights group. Not only was she vicepresident and chairman of the board, but she took an assertive, public role. In reference to a sit-in demonstration in response to segregation within the Diamond and LaSalle Taxi companies, Wills described a run-in with law enforcement: "I was quite visibly pregnant at the time, and when a policeman said to me 'Lady, in your condition you ought to be home', my immediate and spontaneous reply to him was 'If I cannot help create a better world in which to deposit what I am carrying, I may as well not have it, so I don't care what you think, say or do'." 22 Thus in protest, this community leader found validation, especially since the Negro Citizenship Association served as a bastion of moral support for Montreal's black community. It was a place where, in the words of Wills, one could "seek relief from some of the frustrations of this society, due to discrimination, by learning more about our past grandeur."23

As hinted by Wills' allusion to Pan-Africanist thinking, the Negro Citizenship Association was a progenitor for more militant varieties of nationalism. Montreal's African Canadian leadership was increasingly frustrated by the mid-1960s, especially with regard to the Québec government's failure to implement a "full programme of Human Rights Legislation."24 After being pushed several years for anti-discrimination measures in housing and employment, the 
legislative lacuna was perceived as hypocritical given the goals of the Quiet Revolution, an era of "widespread social and economic reform." 25 Employing a language of citizenship appropriate for the time, dissenters equated this oversight with the "humiliating situation as existed in the United States," Canada's foil in matters of race, "prior to the passage of the 1964 Civil Rights Bill."26 Referring to Expo '67, a member of the Association commented during the years leading up to the Exposition on how visitors would receive better treatment than some of the city's hosts who "because of their racial origin will be denied the right to rent apartments of their choice, while many of their guests will have no problem in renting the same apartments..." 27 As a result, there was the sense that discrimination towards black Montrealers was not taken seriously, or portrayed as "insignificant." The organisation's newsletter, Expression, raised the question concerning the role of the government in protecting in its citizens, or more specifically, extending protection to those the law in its current form overlooked. ${ }^{28}$ In light of the federal and provincial authorities' apathetic response to the community's push for legal equality, however, it would have been unsurprising when the Negro Citizenship Association turned to alternative forms of activism, becoming a member of the National Black Coalition, an umbrella organisation which was, as will be discussed, more militant in outlook. ${ }^{29}$

Another possible explanation for the shift among some black Montrealers from integrationist to nationalist views in the 1960 s could be attributed to demographic changes related to immigration patterns. Although racial restrictions were eased in the 1950s to allow for domestic servants, many of whom were from the West Indies, Canadian immigration law did not fully liberalize until 1967, opening the door to those from the so-called Third World, provided they met the selection criteria. In addition to skilled workers, there were significant numbers of students coming to Montreal from the Caribbean during this period. According to historian Sean Mills, West Indian youth came to the city to pursue university studies, often returning home to pursue political careers. They "introduced anti-colonial ideas into Black Montreal, at first upsetting many established members of the community, but ultimately changing the way in which the community conceived of itself and understood its relation to the rest of Québec society and the world at large." Signalling the rise of new Englishspeaking black intelligentsia, a group called the Caribbean Conference Committee on West Indian Affairs (CCC) convened in the mid-1960s. ${ }^{30}$ Further contributing to the heady atmosphere of the time was the Montreal-chapter of the Caribbean-based, New World Group. Working alongside the CCC, this group of academics, which included the economists Lloyd Best and Kari Polanyi Levitt, published the New Work Quarterly, a renowned economic, social, and cultural journal. ${ }^{31}$ The anti-colonial ideologies espoused by these two groups laid the intellectual groundwork for resistance to racial domination in Montreal throughout the late 1960s and 1970s. 
With the aim of building bridges between the Caribbean and Montreal, the Caribbean Conference Committee invited a range of speakers, including the historian, anti-colonial thinker and author of The Black Jacobins: Toussaint l'Ouverture and the San Domingo Revolution, C.L.R. James. By leading study sessions and giving a series of public lectures in 1966, the Trinidadian Marxist's presence had a remarkable impact on the young activists, in particular Tim Hector, Robert Hill, Franklyn Roberts, Anne Cools, and Alfie Roberts, the CCC's core. James would return to Montreal for the Congress of Black Writers in 1968, another galvanizing event for Québec's Black community. ${ }^{32}$ By then, however, a political shift had taken place. As David Austin outlines, more Canadian-born men and women had taken the helm of the community leadership and many members were in Montreal to stay, looking away from Caribbean politics to focus on the well-being of African descended peoples in Canada. Moreover, the influence of the American Black Power movement was increasingly felt. In addition to C.L.R. James and Walter Rodney, notable figures of the U.S. struggle were in attendance at the conference, officially entitled, "The Congress of Black Writers: Toward the Second Emancipation, the Dynamics of Black Liberation.” The star-studded line up even included the charismatic Stokely Carmichael. Setting the scene with regard to women's place within this neo-nationalism, the speakers at Congress consistently addressed the mixed audience as "brothers" and the iconic Miriam Makeba, the wife of Carmichael at the time, never spoke. ${ }^{33}$

Nonetheless, a new kind assertiveness permeated Montreal's black community, a forcefulness, which, as we will see, by no means passed over women. After years of frustration, some community members, especially students, were willing to take a confrontational stance. Thus, when a professor at Sir George Williams University (now Concordia University) was accused of systematically marking down black students, younger community members resorted to civil disobedience. For two weeks in February 1969, a multiracial group of approximately 200 hundred students, including 30 women, occupied the university's Computer Centre, the nerve-centre of the educational establishment. Later known as the Sir George Williams Affair (SGWA), the arrests that followed a mysterious and damaging fire attracted national and international attention, exposing, in the view of some, the racism entrenched in Canadian society. In the first place, the trial of the students in question, which led to the imprisonment of Rosie Douglas and Anne Cools, for eighteen and four months respectively, was arguably biased from the beginning. ${ }^{34}$ Not only had Montrealers been bombarded with media coverage for weeks, focused nearly exclusively on the 48 black protestors, but also the jury consisted entirely of white, middle-class men. Calling upon the principles of fairness and justice, Juanita Westmoreland, the Sorbonne-educated lawyer and former French-language liaison for the Negro Citizenship Association, ${ }^{35}$ denounced the all-white panel as inconsistent with one of the cornerstones of the Anglo-Saxon criminal justice system, that is, trial 
by one's peers. This racial bias was explained by Westmoreland in UHURU, a recently-founded community newspaper:

Only persons who have a common experience can fully understand and appreciate the issues in a particular situation. This principle has been tested and has endured throughout the ages.

No one can say that the fact that all of the 10 accused are black is a coincidence. We maintain that they cannot have a fair trial unless there are also Black people on the panel from which their jury will be chosen. ${ }^{36}$

The Sir George Williams Affair appeared to shake the community to the core precisely because it was representative of something much larger, beyond one incident of prejudice to encompass racial biases in key Canadian institutions. Even though the reactions to the student occupation were varied, the events nevertheless represented a "turning point," altering the leadership's understanding of race relations. ${ }^{37}$ In an editorial published in Expression, for instance, the authors drew parallels between Sir George Williams University and Canada, where the former was the microcosm of the latter. Referring to the country's role in the "underground railroad," and the university's reputation for welcoming immigrant students, the authors wrote, "both enjoy the reputation for fair-play and humanity in their relationships with all groups; both are respected as successful models of a multiracial society." But hidden underneath the surface have been "the covert and often unconscious acts of racism of which Canadians are guilty," from jurors to university administrators. Whereas the racism in the United States was overt, the same phenomenon in Canada was more subtle, yet equally insidious. What was worse was the mythology surrounding the benevolence of race relations, maintained "with traditional Canadian self-righteousness." As the authors concluded, the country was "riddled with paradoxes and contradictions," as "the champion of equality for all races" internationally and rhetorically, while simultaneously overlooking "in silence the unequal treatment of its non-white peoples" at home, namely the Japanese, First Nations and Blacks. ${ }^{38}$ These types of articles multiplied after the Sir George Williams Affair, signalling the reinforcement of a black consciousness and an increasing unwillingness to submit to, or ignore, the structural barriers present in Canadian society. ${ }^{39}$

In a statement to the March 1970 edition of Time Magazine, Dorothy Wills defended the seemingly violent actions of the young students, without condoning them. She attested to the "peace-loving" nature of black people, writing that "regardless of the fierceness of their pride, will not maim or destroy unless pushed to do so in utter desperation." "History can attest to this," she continued, "and despite the outlook I am not convinced that a leopard can change his spots overnight." 40 Despite the more assertive turn in black activism, then, paci- 
fism remained the norm, especially amongst older, more established activists. For many people, Black liberation simply meant "group persistence" in a multi-racial society, where "no one colour group or ethnic group will have more power or prestige than another and in which equality of rights will be guaranteed." 41 Since these ideals were contradicted during the events surrounding the Sir George Williams Affair, however, a faction of the community mobilized to protect its own. The February $11^{\text {th }}$ Defence Committee was established to defend the criminalized students, as was UHURU (Swahili for freedom). The latter started off as a communication bulletin, but soon after become a newspaper espousing internationalist Black Power. ${ }^{42}$ In a letter addressed "Dear Brothers," Stokely and Miriam Carmichael congratulated the publication, as they found it "attempts to deal concretely with the problems our brothers face in Canada and simultaneously continues to deal with an over-all ideology for the Black world." 43 While the newspaper's radical politics were controversial within the Montreal community, there were nevertheless certain ideological underpinnings in common between this segment of the collectivity and the proponents of the more reformist, National Black Coalition. 44 Both embraced Pan-Africanism, and Black Unity regardless of place of birth or geographical location, and were thoroughly implicated in the "Negro-to-Black Conversion" experience. ${ }^{45}$

In other words, there were multiple divisions between Montréalers of African descent, and yet similar experiences with racial prejudice served as a basis for a black identity and activism. So did Pan-Africanism, an anti-colonial ideology fitting for this era of decolonization. More specifically, the concept of "internal colonialism" was implicit in Pan-African thought, considered the "highest form of Black Power" by Stokeley Carmichael. ${ }^{46}$ But as discussed in Sean Mills' nuanced study, the notion of empire was complex in Montreal and black Montrealers were aware of the distinctions between Canadians. While the journalists of UHURU maintained that the community was the object of discrimination at the hands of both the English and the French, they nonetheless recognized the similar forces operating against Francophone Quebecers. FrenchCanadians, for example, experienced difficulty getting hired by Anglo-Saxon-controlled businesses, as did African-Canadians. ${ }^{47}$ Feelings of solidarity went both ways. Throughout the Sir George Williams Affair, many French-speaking leftists came out in support of the students, including the Union générale des étudiants du Québec (UGEQ). ${ }^{48}$ In the pages of UHURU, there was also favourable mention of the Red Power movement; additional proof of Canada's failure to work towards a "Just Society."49 For Rosie Douglas, Canada's record with regard to the extermination of the Indigenous population and the oppression of black peoples was put into the larger perspective of Anglo-Saxon imperialism. In the same article, Douglas examined the role of Canadian businesses and in the $20^{\text {th }}$ century Caribbean, painting their workings as neo-colonial. The presence of Canadian 
troops in Jamaica, supposedly to "acclimatize themselves to tropical conditions for the United Nations," was commented on, in light of the island's potential for socialist revolution. The revolt against racial discrimination at Sir George Williams University, a bourgeois institution with links to the military and corporate elite, thereby took on multiple meanings for anti-colonial activists such as Douglas, who would eventually return to his native Dominica. ${ }^{50}$

While Black Power called into question the very foundations of Canadian society, there were internal divisions within the movement, and not just between the radical and reformist elements. The women within the Black liberation struggle, to varying degrees, were opposed to the subordinate, childbearing role they were supposed to play. Their second-status status was maintained despite the key tasks performed at, for example, the Congress of Black Writers or, like Juanita Westmoreland, in the February Defence Committee. Whether or not the Black Power movement was more sexist than society as a whole cannot be determined but, without a doubt, the language used within nationalist circles was highly masculinist, with a problematic synthesis of manhood and Blackness. ${ }^{51}$ As Dr. C.J. Munford explains to the readership of UHURU:

'Black' is essentially a political term, for its consequences is a militancy that expresses not only the vitality and will to prevail in the Black community, but is also the irreplaceable means by which Black manhood is reasserted. The assertion of Black militancy is the sign of the historic failure of a repressed and constipated white civilization to negate Black virility, the hallmark of the inability of the progeny of Europe to reduce the children of Africa to the level of their own neuter frustrations. ${ }^{52}$

Readers responding to this publication, however, did not always agree. In one letter, signed "a black sister," the reader pointed out that "these brothers have no morale, no manners, no etiquette; they treat the sisters like dirt. Is it this way we want to be a recognized race and happy family?" 53 Yet a point of contention concerned the use of contraceptives, seen by some black nationalists, men and women alike, as a genocidal measure against the "Black, Brown, and Yellow peoples of the world." 54 Although African Canadian journalists, for instance, eventually came to support and promote family planning initiatives, the opposition to birth control and abortion in the late 1960s could also be interpreted as unease with the mainstream women's liberation movement because of the negligible importance placed on race versus the primacy placed on gender. ${ }^{55}$

Similar sentiments were echoed in the writing of Anne Cools, the Barbados-born member of the Caribbean Conference Committee and one of the two SGWA "political prisoners." In an essay, Cools denounced the sexism and racism embedded in the economic and political systems, without denying the 
oppression of her male counterparts. She wrote: "Black women, the slaves of the slaves, can have no peace, no rest until they have evolved new social structures within which men can be Men, women can be Women, and their children, freethinking creative human beings." Though an avid contributor to the discussions of the CCC, Cools followed the same trajectory as many woman involved with the 1960s Left. As David Austin explains, after experiencing the "stifling constraints of participating in groups that were largely controlled by men," like other second-wavers, the only female leader of the CCC became an active feminist, working within the black community, as well as multiracial settings. ${ }^{56}$ For example, Marlene Dixon, an American sociologist teaching at McGill, Anne Cools, and others submitted a brief to the Indochinese Women's Conference, on behalf of the Montreal International Collective. Therein, the authors lauded Montreal as the most important site of revolutionary struggle in North America, and asserted black peoples' right to self-determination. ${ }^{57}$ The young women also participated in the Wages for Housework Campaign with Selma James, the wife of C.L.R. James, and the Montreal Feminist Symposium. ${ }^{58}$ Indicative of the pervasive whiteness within the Canadian women's movement, however, she was the only black woman in attendance at the latter event. ${ }^{59}$ And while Francophone Quebecers credited the influence of American Black Power on their feminism, they did not appear to include Black Montrealers into their gender- and classbased analyses. ${ }^{60}$ All of these instances but especially the first two brought to light the strong international component to Cools' activism, perhaps due to the intertwining influences of Black Power and Pan-Africanism.

Comparable to the United States, then, where black people had achieved legal parity after a long civil rights movement, African Canadians lagged behind in socio-economic equity. Still at a disadvantage in virtually every sphere of society, from the workforce to the education system, black Montrealers were consequently conceiving alternative understandings of their oppression, as we have seen within the context of the SGWA. Thus, they turned to the ideals of Black Power, since the concept of "internal colonialism," as some activists argued, better described their oppression, rather than a liberal understanding of prejudice where only individuals were held responsible. ${ }^{61}$ Meanwhile, in Africa and the Caribbean, formal independence had been achieved for many countries, yet the economic domination of these newly-established states persisted, leading to new patterns of colonialism, or "neo-colonialism." According to political scientist Robert Williams II, the "inherent ills" of global capitalism and racialism negatively impacting African descended peoples around the world served to join the North American and Third World struggles together. The most obvious manifestation did not occur in the 1960s, but instead in 1974 with the $6^{\text {th }}$ PanAfrican Congress, held in Tanzania. Every continent was represented at the $6^{\text {th }}$ PAC, from South America to Europe. The event "marked the beginning of revo- 
lutionary Pan-Africanism," a movement with strong echoes in Montreal, for both men and women. ${ }^{62}$

\section{Black Women's Diaspora Activism}

Building on their previous linkages with the Caribbean, the Montreal black community continued to inscribe its activism in an anti-colonial, yet more specifically Afro-centric framework by the early 1970s. Women were key contributors in this shift, with a vested interest in forming alliances with black

Diasporas all over the world. On the occasion of an African Liberation Day rally in 1972, Dorothy Wills, going by her adopted name Abike, called on her "brothers and sisters" to help Africa to become "truly free and independent, because in so doing we are helping ourselves." She outlined the difficulties faced by the new African countries subjected to the Western-controlled market, and the challenges of being African descended in Canada, a country where blacks were "constantly crushed, hurt, brutalized, and dehumanized." International black unity was one answer to overcoming this oppression, or, in the words of Wills, a means to reclaim a sense of self, to "do what needs to be done in order to realize my full potential and be a real person." For this community leader, then, like the other Pan-Africanists of her time, the presence of the white power structure at home and ongoing economic domination abroad contributed to a far-reaching notion of "our brother's keeper." 63 By no means looking past the socio-economic barriers at home, the everyday tactics behind the amelioration of black peoples' lives employed by community leaders were on the contrary now embedded in a larger, collective quest for equality, where a weak regional community could hinder the global Pan-African movement. ${ }^{64}$

In Montreal, a city with a relatively small black population, the internationalist rhetoric offered by Pan-Africanism resonated strongly, serving as a morale-boosting vocabulary to confront the challenges of daily life in an extreme minority situation. The image of an African motherland, even if romanticized, fuelled the activism of many black Montrealers, but especially those of West Indian origin. In fact, North American-based activists born in the Caribbean, from Marcus Garvey to Stokely Carmichael, were over-represented in the PanAfricanist movement. ${ }^{65}$ The autobiography of Rosemary Brown, the Jamaicanborn feminist politician who passed through Montreal before moving to Vancouver, offers insights into why this might be the case: coming out of the educated middle-classes, these immigrants were exposed to anti-colonialism from an early age. Their migration to Canada or the United States, often to further their schooling, perhaps led to reconfiguration of their political beliefs, this time with a lived understanding of an international black community and the difficulties of being in a majority white society for the first time. ${ }^{66}$ Like their Garveyite predecessors, then, 1970s Pan-Africanists adhered to the notion of a "black 
international." Not only did West Indians continue to play an integral role in this re-conceptualization of nationhood, but also so did women.

As a member of the Negro Citizenship Association, the Dominicaborn Dorothy Wills continued to frame resistance in terms of unequal access to socio-economic resources. For this activist, however, Pan-Africanism was now the answer to the second-class citizenship status faced by black peoples in Canada:

Do you have any idea the psychological implications for you and I if we were to live to see the liberation of Afrika? Can you imagine what dual Citizenship would mean to you and I and all Black people? It would mean that we would have an alternative available to us -that we would no longer be doomed to a life sentence of white domination -but we would have the choice of going back home where we originated -indeed where human life originated. ${ }^{67}$

Although Rosemary Brown later became the first Black woman to be elected to political office in 1972, as evidenced by the articles in UHURU, African Canadians generally perceived the electoral system to be out of reach. ${ }^{68}$ As a result, there was an emphasis on community-based activism, a form of politics whose proponents did not automatically seek incorporation into the state apparatus. Since Black Nationalists understood the structural barriers they faced as being part of a larger dynamic, as we have seen with the CCC and the SGWA, the activism they professed was organized accordingly. Furthermore, because local community organising - leading to transnational connections - lay in the informal sphere, women could wield more influence. Indeed, feminist scholars refute the notion that women are less political than men by pointing to women's participation outside the parameters of the formal political process. ${ }^{69}$ The same could be said for African Canadian women's activism in Montreal. This reality had the perhaps unintended consequence of allowing a space for women on the international stage, in the capacities of "unofficial" diplomacy.

For instance, Dorothy Wills was a delegate to the 1974 Sixth PanAfrican Congress (PAC), monumentally held on African soil, in Dar es Salaam, Tanzania. This gathering of activists of African descent from all over the world was also the first time women's issues were addressed at a PAC. Delegates from a range of countries and organisations resolved, "to give [their] total support to the political struggles for equality undertaken by black women" as well as "tackle the problems of the oppression of women thoroughly and profoundly." In spite of these noble claims, women's voices were still marginalised, since very few of the published documents included, or were authored, by women. It was not until the $7^{\text {th }}$ Pan African Congress convened in Kampala, Uganda in 1994 that feminist demands were explicitly placed on the agenda. ${ }^{70}$ Nevertheless, Dorothy 
Wills commented extremely positively on her experience in Dar es Salaam, where as guests of the Tanzanian government, African Canadians "were extended the hand of brotherhood, and treated like long lost relatives." She described the Congress as "edifying, gratifying, intellectually stimulating, and emotionally satisfying" in the National Black Coalition of Canada newsletter she edited, Village News (also known by its Swahili name, Habari Kijiji). ${ }^{71}$ In August of the same year, during a speech Wills gave in Nova Scotia and later re-published in Contrast, the black newspaper with the largest circulation in Canada, she reported that "it was beyond description to see, assembled in Nkrumah Hall, Blacks from around the world seeking a solution to problems which we all face."72

As evidenced by Montreal's delegation to the $6^{\text {th }}$ Pan-African Congress and the foundation of the National Black Coalition of Canada in 1973, an umbrella group linking, for example, the Guyana Association of Toronto and the Nova Scotia Association for the Advancement of Coloured People, African Canadian leaders fostered a nation-building process, establishing autonomous institutions, boundaries of nationhood, as well as Afro-centric values. In Dorothy Wills' African Liberation Day speeches, for instance, Julius Nyerere's African socialism, or ujamaa was held up as a foil to North American "individualistic" and "materialistic" society."73 The radically anti-colonial ideology based on the extended family was conceived as a method of doing away with Western, capitalistic ways of thinking. By encouraging black peoples across the world to embrace each other as brothers and sisters, the family to which they belonged to extended "beyond the tribe, the community, the nation, or even the continent."74 When reporting on the adhesion of the NBCC to the "Committee of Many," the brainchild of the Elders of the Black Community conference in Chicago, Dorothy Wills encouraged this logic, because as an immigrant leader for a predominately foreign-born community, she like her counterparts was looking for, in her words, "a sense of belonging... which is so lacking in our huge impersonal metropolitan cities."75 Pan-Africanist ideology was therefore not only an idiom of critique and resistance, but also served as a means to bring together on positive terms a culturally disparate Canadian, Montreal, and global black community.

Similarly, the Black Value System permeated the rhetoric of the community leadership, serving as an ideological basis for autonomy. During a "think in" on black culture, Dorothy Wills pointed to the role these Afrocentric principles: unity, self-determination, collective work and responsibility, cooperative economics, purpose, creativity, and faith- could serve in encouraging the next generation to participate in the struggle. One way to advance intergenerational solidarity and pride was to create a separate school system, presented by Wills in Pan-Africanist fashion, as a means to restore "our former grandeur." 76 Relying upon her capacities as a teacher, and perhaps her experience at the 1973

Educators for Africa Workshop as well, ${ }^{77}$ Wills promoted parallel educational 
initiatives such as the Dacosta-Hall Summer Programme in order to offset the racist presumptions of white teachers in day schools. By learning in an Afro-centric milieu, according to some leaders, black identity could be positively reinforced. ${ }^{78}$ Because like other minorities, Montrealers of African descent were systematically channelled into the vocational-technical stream and consistently portrayed as invisible to the Canadian social fabric through an ethnocentric curriculum. ${ }^{79}$ Or as Dorothy Wills stressed during a presentation to the Protestant School Board of Montreal, "White Canadians tend to see all Blacks as immigrants anyway, and treat us as such whether we just stepped off an Air Canada Flight from the Caribbean or claim to be fifth generation Canadian." 80 In other words, the predominant perception of African Canadians as exotic Others led to parallel institution-building, the necessity of which not only bolstered internationalist Black Nationalism but also the appropriation of a racialized national identity, hence the NBCC choosing the Black maple leaf as its symbol. ${ }^{81}$

For Black Nationalists, the Black Value System and the Extended Family of Black People were not recent developments. Rather, they served to reclaim a painful past, simultaneously projecting the globally dispersed African nation into a brighter future. As one Black Scholar author wrote, "We can build ourselves into a conscious nation once again-that we can free ourselves, from the chain of white commitment..." As in the case in other "modern" nations, then, African Diaspora history in part served nationalistic purposes. ${ }^{82}$ As a Black woman, Wills and others like her could have had a vested interest in this diasporic re-conceptualization of nationhood, seeing less barriers, less rigid hierarchies with which to contend outside the official workings of the racist and sexist nation-state. ${ }^{83}$ Perhaps women of African descent would have gladly reappraised their role in history for the reason that within this interpretation they not invisible, as they were in the Canadian (and Québécois) national narrative. ${ }^{84}$ Because in the Pan-African version of events, as Montreal's foremost woman community leader explained, they were instead the mothers of the "great militarists of antiquity" and the descendants of "the Queens of Ethiopia and Egypt." 85 Stated otherwise, a revisionist understanding of history was linked to Pan-African, as well as arguably African Canadian notions of nationhood. And for Dorothy Wills, at least, it included a gendered component, allowing for the previously unacknowledged historical presence of black women in Canada and elsewhere.

In sum, the Black Value System, combined with African socialism and reinforced by a renewed, sometimes romanticized interest in African and Diaspora history, provided the intellectual and ideological basis for a worldwide, "imagined community" of black peoples. Of course the nation-building tactic was more in the realm of the theoretical than based on everyday experience but this type of rhetoric did nonetheless serve as an impetus, a direction for local activism. ${ }^{86}$ Community organising on the ground translated into cross-border 
alliances, both imaginary and, in some cases, real, because, in fact, the revolutionary Pan-Africanist atmosphere of the times allowed for face-to-face meetings. Wills, for instance, used her time in Dar es Salaam strategically, speaking "with as many representatives of the liberation groups as possible in an attempt to discover how we, on the North American continent, could assist in the struggle for the liberation of Africa... without being on the African continent." In Tanzania, this woman activist discovered that printing costs were very high, so since coming back to Canada, she printed and resent 2000 copies of PAC Azania's propaganda booklet. ${ }^{87}$ More than a practical response, however, sending printed material served to reinforce, or even create, affective and personal ties between Africa and the Montreal Diaspora. In effect, Pan-Africanism since its inception at the turn of century was frequently termed Black Zionism, in that, now far-flung peripheries looked to another centre, one where they were not necessarily born. $^{88}$

Like the establishment of Israel for World Jewry, the formation of independent of African nation-states served to shift the focus of Black peoples towards the "Motherland." 89 Thus, as decolonization accelerated, people of African descent, including, and perhaps especially, those born in the Caribbean, directed their attention to the African continent, creating diasporic linkages where ones did not exist before. For example, Dorothy Wills, as previously mentioned, printed and shipped anti-apartheid propaganda booklets, and, indeed, her contribution to the South African liberation movement was greatly appreciated. She was described as "a great soul, real daughter of Mother Afrika" by the author of one letter, Elias L. Ntloedibe of Dar es Salaam. ${ }^{90}$ Also writing from Tanzania, Okdt Bernard R Seme's letter in 1975 echoed a similar sentiment:

"I am taking this opportunity to say thank you very much for all you did to us and the kindness you showed us while we were in [Montreal].... The feeling I had while I was there is of the kind that makes someone less lonely and more at home than ever. We have mothers, fathers, sisters and brothers in Canada." 11

Wills was therefore a well-respected activist of Pan-African renown, further confirming the reputation of black women regarding the key and recognized role they played within the community, in this case, worldwide. ${ }^{92}$

Dorothy Wills' excellent reputation indeed extended back to Montreal. Reporting on the foundation of the National Black Coalition in Contrast, a journalist wrote: "You didn't hear so much about women's lib at that time, but the men who knew of her abilities had no doubt that she would lead the [NBCC] before long," which she eventually did in 1972. Her leadership position was never called into question during this period because "you felt she had the talent experience and charisma to make it work." 93 Positive feelings went both ways. When honoured at the Black Awards Banquet in 1976, Wills described the moti- 
vating force behind her involvement when she said, "It is a tremendous feeling of reciprocal love by the Black Community." Despite the mutual singing of praises, however, the woman activist was still dubiously hailed by the newspaper as "a brilliant example of a Black woman's contribution to the Black man's struggle for liberation." 94 These questionable semantics, even if offhand, were nonetheless indicative of the lack of extensive gender-based analyses within the CCC and the NBCC. 95 This significant analytic oversight was in contrast to the various forms of Black Nationalism, Marxism, and Socialism discussed at length by these organisations' leaders and in the Black world more generally. ${ }^{96}$ In other terms, the "woman question" was not fully incorporated into many forms of Black thought.

Yet membership in Montreal's male-dominated political groups did not preclude women leaders from founding their own organisations. On the contrary, the Congress of Black Women (CBW) became a major institution within the community as of the early 1970s and its events were regularly reported on by Village News. ${ }^{97}$ As scholars and activists Shirley Small and Esmeralda Thornhill explain, the Quebec-chapter of the Congress had its origins in the Coloured Women's Club of Montreal, in that, the CWC organized and hosted the overwhelmingly successful Second Congress of Black Women, held in 1974. Dorothy Wills described the galvanizing effects this meeting had on Black women: "What can we say, except that we seem to be becoming more self-sufficient each day as we acquire the necessary skills to run our own show? Maybe one day we will run our own community and it will be a glorious day." 98 Differentiating the Congress from its predominately white, feminist counterparts, the autonomous women's organisation stressed "the centrality of race and racism" in the lives of black women, as well as the reality of "triple-oppression", that is, "race/gender/class." As an unabashedly Afro-centric umbrella group, the Congress aimed to fight the structural barriers prohibiting the socio-economic advancement of native- and foreign-born black Canadians regardless of gender with the help of long-standing community activists. ${ }^{99}$

Writing on black feminism in Britain, Hazel V. Carby argues that key concepts such as the family, patriarchy and reproduction which are "central to feminist theory become problematic in their application to black women's lives." 100 As we have seen already with regard to contraception and abortion, Montreal-based African Canadian women struggled with these issues, albeit in different ways than middle-class white women. These tensions continued into the 1970s. For example, the Committee addressing issue of birth control at the 1973 Congress of Black Women, which included Anne Cools, was prepared for serious discussion on the matter; however the conversation was deemed inappropriate "once the subject of 'Genocide' was raised from the floor." Yet as Rosemary Brown stated at the same conference, "I cannot accept the theory that 
the most valuable contribution that I have to make to the Black struggle is that of giving birth to additional Black male children."101 As the two conflicting perspectives portrayed would illustrate, Black women could not separate their "blackness" from their "femaleness," hence the emotional debates surrounding some of the cornerstones of the more mainstream, and predominately white, women's liberation movement, such as reproductive rights. ${ }^{102}$

The black woman's role within the family was also perceived differently. The same year Dorothy Wills went to Dar es Salam, she authored a series of articles in Contrast entitled "The Status of the Black woman today." Exemplifying the political leanings of their author at the time, these articles were infused with Pan-African language: "The role of the Black woman in the liberation struggle cannot be underestimated and this is the way it ought to be. We have a role to play wherever we are." When in Tanzania, black women brought medical supplies to freedom fighters and donated blood and, in Canada, they had an integral role to play in the family, raising children to embody the Black Value System. ${ }^{103}$ By heading important community institutions and traveling to the United States and Africa, Wills was evidently not an advocate of a passive, subordinate role for women. For this activist, revolutionary motherhood was instead a means to counteract the hegemonic whiteness faced by African Canadians when, for example, children were racially slighted at school and came home in tears, seeking comfort. By transmitting racial pride to children, the reasoning went; they would grow up ready to contribute to the struggle. For Wills and others like her, mothers played the all-important role of dictating, "the shaping of tomorrow and the building of the Black nation." Through their empowerment in the home, black women thus contributed to the well-being of their families and, by extension, the entire community because "a nation is comprised of units."104

In other words, African Canadian women had divergent attitudes towards gender roles. Patriarchy operated in a different framework for black women; hence the status of women appeared more complex. While activists held up the family as a bulwark of resistance in a racist society, they nonetheless maintained a discourse open to critical analysis. ${ }^{105}$ Because white families were adopting a number of black babies, for example, the community was undergoing a soul-searching process. As Karen Dubinsky examines in her sensitive study on interracial adoption, both white and black men sometimes took young women working in white homes advantage sexually. Some had children out of wedlock and were forced, out of circumstance, to put their children up for adoption. ${ }^{106}$ Numerous sides of this issue were indeed addressed at the 1973 Congress of Black Women from the pitiful assistance available to single mothers and the racial biases in the social service sector, to the community's attitudes towards young mothers and intra-communal adoption. ${ }^{107}$ Faced with a different, and perhaps more demanding, set of challenges than white women, attitudes to their 
families ran parallel, where the family was prized and unity amongst kin was cherished. ${ }^{108}$

Further underlining the specificity of the black women's movement in Montreal, the Congress of Black Women was an inherently transnational women's organisation, paying much greater attention to happenings abroad. As we have seen, black women were imbued with the ideologies of Black Power and Pan-Africanism and often employed them in mixed-gender settings, like the $6^{\text {th }}$ Pan-African Congress. These two modes of thought carried over to the political activities of women's-only groups. In the an article on "consciousness raising," published in the 1977 proceedings of the Congress of Black women, Agnes Calliste, a Grenada-born sociologist, argued for a "unified effort, not only among Black women in Canada but among Black women throughout the world." Evoking the writings of Frances Beal, the American civil rights activist and founder of the Third World Women's Alliance, Calliste continued: "For despite the differences in our cultural backgrounds, we have one thing in common: the double jeopardy of being Black and female."109 Translating thought into advocacy, the women of the CBW expressed their "solidarity with struggles of peoples of Namibia, Zimbabwe, and South Africa for their liberation against colonialism and from apartheid and demands that the Canadian government stop any form of aid to the racist government of Ian Smith and L. Vorster." They also demanded that the Canadian government intervene on behalf of the husbands of two Haitian women living in Montreal, Françoise Ulysée and Lisette Romulus, who were being held and tortured in Haiti at the hands of the Duvalier regime. ${ }^{110}$ In fact, the Congress of Black Women was the most vocal, predominately English-speaking black organization opposed to the deportation of 1500 Haitian Montrealers in the early 1970s. ${ }^{111}$

Even in feminist contexts, then, African Canadian women maintained an internationalist mindset. So when the Congress of Black Women resolved to intervene in favour of including domestic servants under the minimum wage act, insisting the latter benefit from social security measures, or attended the trial of Haitian exiles facing deportation defended by Congress member Juanita Westmoreland, they were not strictly acting within the national sphere, but as members of a global Diaspora. ${ }^{112}$ In other words, Montreal's women activists continued to exercise a form of "dissident transnational citizenship" by attempting to protect the rights of community members who bore the negative consequences of the international political economy, extending beyond the borders, yet intrinsically related to the First World country where they resided. ${ }^{113}$ Despite these far-reaching focuses, however, one criticism levelled at the Congress of Black Women was the relatively homogeneous socio-professional make-up of its participants. In a 1977 article published in Contrast, a journalist begged the question: "In a congress intended to address itself to the problems of the average 
black woman, where was the domestic, the factory worker? One would hardly expect to find her in the carpeted corridors of the Holiday Inn." The author nevertheless acknowledged the necessity of this feminist get-together, because, as he or she wrote, "It is this group of people that will lay the foundations of a nation-wide black women's organisation."114

While perhaps not entirely representative of the community the women in attendance, nonetheless representing a wide-range of ages and national provenances, were still undertaking the all-important work of reconciling the competing, though not mutually exclusive liberation movements transforming their community. As Rosemary Brown stated in the opening remarks of the 1973 Congress of Black Women conference:

I made the choice for liberation because I believe in our men $-\mathrm{I}$ believe that they are strong enough to accept me as an equal - and to join with me and stand with me in my struggle to be myself even as I stand and will always stand with them in theirs, and I know that we must work in and draw strength from both of these liberation struggles if we are to listen struggles if we are to hasten the day when the dream of those early pioneers is realized -and we all live truly equal human beings in this country. ${ }^{115}$

Stated otherwise, the two activisms ultimately fed off each other. As Brown took the pains of explaining, women's liberation did not "drain her energies," taking away valuable time from the black struggle. On the contrary, the women's movement was "strengthening" her, as she had greater faith in her own abilities, bringing to the broader community a greater confidence and ultimately contributing to the liberation of both Black men and women. ${ }^{116}$ By this logic, suppressing the contribution of black women would hinder the entire movement. For African Canadian feminists, then, the notion that women should be relegated to a subservient role within the revolution not only perpetuated male domination, but also white supremacy. ${ }^{117}$ Jaded after years of discrimination, Rosemary Brown was neither "concerned nor surprised" at the racism she knew existed within the women's movement. For this activist, the difficulty was convincing other black women of the necessity to engage with feminist issues in addition to questions of race. ${ }^{118}$

In conclusion, English-speaking Caribbean women's cultural and political background allowed them to employ a radical, Pan-Africanist lens to their socio-economic position, joining forces with Canadian-born black people, men and women, in order to challenge the subtle racism pervading Montreal society. Because Canadian institutions failed to fully take into consideration the needs of these citizens, the community turned to ideologies of worldwide black nationhood, as a framework to facilitate links with other Black Diasporas. The connec- 
tions between black peoples whether in Chicago, at the Elders of the Black Community conference, or in Tanzania, at the $6^{\text {th }}$ Pan-African Congress, solidified a parallel, inherently diasporic identity. Even if an autonomous women's organisation, the Congress of Black Women still relied upon the same ideology and methods as other community organisations, that is, black consciousness, local organising, and internationalist perspectives. Organic to the community and intrinsically related to the Black struggle, African-Canadian women's activism of the 1960s and 1970s exemplified perhaps, another type of "double-consciousness," one where women's issues were taken into consideration. Thus, AfricanCanadian women ultimately promoted a strand of feminism inseparable from this form of Black Nationalism, yet still critical of its masculinist components. Given the emphasis on human liberation within some manifestations of PanAfricanist thought, this brand of activism was an extension, not a break, from the latter. ${ }^{119}$

Coming from the standpoint of a minority in overwhelmingly white city, Montreal Blacks embraced Pan-Africanism precisely because it allowed them to inscribe their fight for equality at home within a more powerful activism of global proportions. Yet, this looking away from the federal and provincial authorities to the happenings within other Black communities was more so a response to the racial biases embedded in the institutions defining the lives of African descended Montrealers, from legal legislation to the justice system, from social services to women's organisations, than a desire for black separatism, again, perhaps, due to the relatively small size of the community. It must also be specified that the idealized return to Africa was in actuality rarely evoked or carried out. Activists like Dorothy Wills were instead adapting and contributing to the new reality in Québec including the shift towards French and a more assertive Francophone nationalism, though exactly how Montreal English-speaking Blacks fit in to René Lévesque's post-Bill 101 Québec remains nebulous. This paradoxical reality, where black Montrealers made connections with their counterparts in Africa and other Diaspora centres, but never left for Zion, points to the porous boundaries of the nation-state and further refutes the singular identification its most vehement proponents demand. More research, however, is needed to shed light on these questions, especially complex in the Québec context. 


\section{NOTES}

This article benefited from conversations with John Zucchi, Suzanne Morton, Sean Mills, Rachel Sandwell, Colin Grittner, and Lana Povitz. The author also wishes to thank the anonymous reviewers at Left History for their valuable feedback. Research for this article was supported by SSHRC.

1 See Sean Mills, The Empire Within: Postcolonial Thought and Political Activism in Sixties Montreal (Montreal \& Kingston: Queen's-McGill University Press, 2010).

2 Becky Thompson, "Multiracial Feminism: Recasting the Chronology of Second Wave Feminism," in No Permanent Waves. Recasting Histories of U.S. Feminism, ed. Nancy A. Hewitt (New Brunswick, New Jersey: Rutgers University Press, 2010), $40-41$.

3 See, for example, Andrea Davis, "A Feminist Exploration in African Canadian Literature," in Multiple Lenses: Voices from the Diaspora Located in Canada, ed. David Divine (Newcastle: Cambridge Scholars Publishing, 2007), 250, 260; Charmaine Crawford, "Sending Love in a Barrel: The Making of Transnational Caribbean Families in Canada," Canadian Women's Studies 22, 3, 4 (Spring/Summer 2003), 104-109; Notisha Massaquoi and Njoki Nathani Wane, eds. Theorizing Empowerment: Canadian Perspective on Black Feminist Thought (Toronto: Inanna Publications and Education, 2007), 6.

${ }^{4}$ Joan Sangster, Through Feminist Eyes: Essays on Canadian Women's History (Edmonton: Athabasca University Press, 2011), 20.

5 See Carolle Charles, "Gender and Politics in Contemporary Haiti: The Duvalierist State, Transnationalism, and the Emergence of a New Feminism (1980-1990)," Feminist Studies 21 (Spring 1995), 135-64.

6 See Daiva Stasiulis, "Relational Positionalities of Nationalisms, Racisms, and Feminisms," in Between Women and Nation: Nationalism, Transnational Feminisms, and the State, eds. Caren Kaplan, Norma Alarcon, and Minoo Moallen (Durham, NC: Duke University Press, 1999), 182-218.

${ }^{7}$ David Austin, "All Roads Led to Montreal: Black Power, the Caribbean, and the Black Radical Tradition in Canada," The Journal of African American History 92, 4 New Black Power Studies: National, International, and Transnational Perspectives (Autumn 2007), 516-539.

8 Stéphane Dufoix, La dispersion: une histoire des usages du mot Diaspora (Paris: Éditions Amsterdam, 2011), 249, 259-260; Paul Gilroy, The Black. Atlantic: Modernity and Double-Consciousness (Cambridge, M.A.: Harvard University Press, 1993), 127.

${ }^{9}$ Dorothy Williams, The Road to Now The Road to Now: a History of Black in Montreal (Montreal: Véhicule Press, 1997), 58-60; The term "long black sixties" was used in Michael O. West and William G. Martin, "Contours of a Black International: From Toussaint to Tupac," in From Toussaint to Tupac: The Black International since the Age of Revolution, eds. Michael O. West, William G. Martin, 
and Fanon Che Wilkins (Chapel Hill: The University of North Carolina Press, 2009), 22, 26.

10 Charmaine Nelson, ed., Ebony Roots, Northern Soil: Perspectives on Blackness in Canada (Newcastle: Cambridge Scholars Publishing, 2010), 17.

11 Jared G. Toney, "Locating Diaspora: Afro-Caribbean Narratives of Migration and Settlement in Toronto, 1914-1929," Urban History Review 38, 2 (Spring 2010): $75-87,75$.

12 In addition to the above-mentioned works by Andrea Davis, Charmaine Crawford, Notisha Massaquoi \& Njoki Nathani Wane, Jared Toney, and Charmaine Nelson, there have also been notable contributions from Jenny Burman and James W. St. G. Walker. See, for example, Transnational Yearnings: Tourism, Migration, and the Diasporic City (Vancouver: University of British Columbia Press, 2010) and "Black Confrontation in Sixties Halifax," in Debating Dissent: Canada and the Sixties, eds. Lara Campbell, Dominique Clément, and Gregory S. Kealey (Toronto: University of Toronto Press, 2012), 173-191. ${ }^{13}$ Ibid., 13-14. 14 Ibid., 50-52.

15 Mills, The Empire Within, 97-98; West and Martin, "Contours of a Black International: From Toussaint to Tupac," 22, 26.

16 "Introduction," The Black Scholar, February 1971, 1.

17 Library and Archives Canada (LAC), Dorothy Wills Fonds, MG 31 H179 Volume 5, File 5-1: National Black Coalition of Canada "The National Black Awards of Canada" 1976 Forward by Abike (Dorothy Wills), Extract "Dorothy Willis: The Persistent Apostle of Identity, Unity, Liberation."

18 LAC, Dorothy Wills Fonds, MG 31 H179 Volume 1, File 1-1: Dorothy Willis: Curriculum vitae, biographical information, and professional associations, "Curriculum Vitae."

19 The Black Scholar took up the entirety of volumes 11 and 12 of the Dorothy Wills Fonds. See MG 31 H179 Volumes 11, 12. Further indicative of the intellectual influences on this community leader, in a paper Wills gave to the Alliance of Africans in Quebec, she cited Albert Memmi, W.E.B. DuBois, Aimé Césaire, and Patrice Lumumba. See LAC, Dorothy Wills Fonds, MG 31 H179 Volumes 1, File 1-8: File of personal correspondence titled "The Struggle and Me" 19811983. Dorothy Wills, "Black Identity" Presented to: The Alliance of Africans in Quebec; Holiday Inn Hotel (420 Sherbrook Street West); Date: May 25 $5^{\text {th }}, 1979$. 20 McGill University, Rare Books/Special Collections-Roy States Collection, Richard E. Leslie, "The Negro Citizenship Association Inc. Philosophy and Objectives," Expression February 1965, 3-6.

21 LAC, Some Missing Pages: The Black Community in the History of Quebec and Canada. Primary and Secondary Source Materials (Government of Québec: Ministry 
of Education, 1985), 164.

22 LAC, Dorothy Wills Fonds, MG 31 H179 Volume 5, File 5-2: National Black Coalition of Canada -Dorothy Willis' address to the NBCC 1982, 1984, "Response to an Award Given by the National Black Coalition of Canada."

${ }^{23}$ LAC, Dorothy Wills Fonds MG 31 H179 Volume 8, File 8-2: States, Roy W. Tribute by Dorothy Willis at the Memorial Service, Union United Church.

Montreal Dec. 14th 1980 , "Tribute to Roy Wellington States."

24 R.E.I, “Editorial,” Expression, January 1966, 3-5.

25 Lara Campbell and Dominique Clément, "Introduction: Time, Age, Myth:

Towards a History of the Sixties," in Debating Dissent: Canada and the Sixties, eds. Lara Campbell, Dominique Clément, and Gregory S. Kealey (Toronto: University of Toronto Press, 2012), 13.

26 This terms "foil" with regard to Canada's relationship to the United States in matters of race and racism was used by Karen Dubinsky in Babies without Borders: Adoption and Migration across the Americas (Toronto: University of Toronto Press, 2010), 79.

27 R.E.I., "Editorial," Expression, February 1965, 7-9.

28 "Editorial," Expression, July 1967, 3-4.

${ }^{29}$ LAC, Dorothy Wills Fonds, MG 31 H179 Volume 4, File 4-18: National Black Coalition Umoja-Black Dialogue, newsletter edited by Clarence Bayne and Dorothy Wills, "Organisations Represented in the National Black Coalition," Umoja: Black Dialogue, October 20th $1969,1$.

30 Mills, The Empire Within, 97-98.

31 Austin, “All Roads Led to Montreal," 520.

32 Alfie Roberts, A View for Freedom: Alfie Roberts Speaks on the Caribbean, Cricket, Montreal, and C.L.R. James. Introduction by David Austin, afterward by Robert Hill (Montreal: Alfie Roberts Institute, 2005), 71-72.

33 Austin, "All Roads Led to Montreal," 521, 523.

34 Ibid, 531-532; Marcel Martel, "'Riot at Sir George Williams: Giving Meaning to Student Dissent," in Debating Dissent: Canada and the Sixties, eds. Lara Campbell, Dominique Clément, and Gregory S. Kealey (Toronto: University of Toronto Press, 2012), 97.

35 Richard E. Leslie, "The Negro Citizenship Association Inc. Philosophy and Objectives," Expression, February 1965, 3-6.

36 LAC, “Canadian Justice in Operation," UHURU, February 2 ${ }^{\text {nd }}, 1970,1$.

37 Martel, "'Riot at Sir George Williams: Giving Meaning to Student Dissent," 109-110.

38 "Canadian Liberalism: Fact or Fiction?," Expression, Winter 1986, Special Conference Issue, 3-6.

${ }^{39}$ For an understanding of a Montreal Black collective consciousness, see 
Austin, "All Roads Led to Montreal," 535. As will be discussed, those involved in defending the students founded UHURU, a community newspaper espousing Black Power.

40 LAC, Dorothy Wills Fonds, MG 31 H179 Volume 7, File 7-19: Addresses by Dorothy Willis delivered to Black Graduations and Community Dinners (19681975), Dorothy Wills, “Statement to Time Magazine," March 1970.

41 St. Clair Drake, "The Black Diaspora in Pan-African Perspective," The Black Scholar, September 1975, 2-13.

42 Mills, The Empire Within, 112.

43 Stokely and Miriam Carmichael, "Letters," UHURU February 2, 1970, 2.

44 Austin, “All Roads Led to Montreal," 521.

45 See, for example, LAC, Dorothy Wills Fonds, MG 31 H179 Volume 4, File 420: National Coalition of Canada Habari Kijiji (Village News) Newsletter edited by Dorothy Wills, William E. Cross Junior, "The Negro-to-Black Conversion Experience," reprinted in the June 1975 edition of Village News.

46 See, for example, the book Carmichael co-authored. Stokely Carmichael and Charles V. Hamilton, Black Power: The Politics of Liberation in America (New York: Vintage Books, 1967), 2-6.

47 Mills, The Empire Within, 115.

48 Ibid, 107; Martel, "'Riot at Sir George Williams: Giving Meaning to Student Dissent," 103.

49 Asher, "Red Nationalism on the Rise," UHRURU March 2, 1970, 7.

50 Rosie Douglas, “Canadian Racism and Sir George," UHURU, February 2, 1970, 4-5.

51 As Kathleen Cleaver, a prominent Black Panther Party member explains with regard to the gender dynamics within the party, "When women suffered hostility, abuse, neglect, and assault-this was not something arising from the policies or structures of the Black Panther Party, something absent from the world-that's what was going on in the world. The difference that being in the Black Panther Party made was that it put a woman in a position when such a treatment occurred to contest it." See Kathleen Cleaver, "Women, Power, and Revolution," in Liberation, Imagination, and the Black Panther Party, eds. Kathleen Cleaver and George Katsificas (New York: Routledge, 2001), 126.

52 Dr. C.J. Munford, "Feature Articles: On the Importance of Being Black," UHURU, July 31, 1969, 4.

53 A Black sister, "Dear Sister," UHURU, September 15 th $, 1969,6$.

54 An admirer, "Dear Sister," UHURU, January 12th $1970,6$.

55 Black news sources moved away from a virile language. For family planning initiatives, in particular for men, see LAC, Kenyon Burke, "Sexual Responsibility for Males," Contrast, March 10 $0^{\text {th }}, 1977,15$. 
56 David Austin, "An Embarrassment of Omissions, or Rewriting the Sixties: The Case of the Caribbean Conference Committee, Canada, and the Global New Left," in New World Coming: The Sixties and the Shaping of Global Consciousness, eds. Karen Dubinsky, Catherine Krull, Susan Lord, Sean Mills and Scott Rutherford (Toronto: Between the Lines, 2009), 368-370.

57 Simon Fraser University Archives, Women's Movement Collection, F-166, File 2: Indochinese Women Conference, The Montreal International Collective, “Memorandum to the Interim Work Committee," December 19th 1970. The signers of the memo were Anne Cools, Marlene Dixon, Estelle Dorais, Susan Dubrofsky, Vickie Tabachnik, and Eileen Nixon.

58 David Austin, "An Embarrassment of Omissions, or Rewriting the Sixties: The Case of the Caribbean Conference Committee, Canada, and the Global New Left," 370; In the words of Akua Benjamin, a Trinidadian-Torontonian: "Anne Cools came to one of these meetings, and she blasted the men. She challenged us women in the room as to why we were not talking. In those days, I just sat quietly in the back of the room. I would sit there and sweat. I was afraid to speak, afraid that I would get shut down. Anne cursed the men out, saying, 'fucking' this and 'fucking' that. We had never heard a woman talk like that. She really empowered me. After that I thought, 'I'm going to raise my voice'." Quoted from Judy Rebick, Ten Thousand Roses: the Making of a Feminist Revolution (Toronto: Penguin Books, 2005), 9-10.

59 LAC. Dorothy Wills Fonds, Dorothy Wills Fonds, MG 31 H179 Volume 2, File 2-14: Cools, Anne, Canada's First Black Senator: clippings file 1984, “Ann Cools: Close-Up with Charles Harding: 'Jail is torment'," The Nation, Sunday, March 24, 1974, 8.

${ }^{60}$ For references to the influence of the African-American struggle see Véronique O'Leary and Louise Toupin, eds., Québécoises Déboutte! Tome 1. Une anthologie de textes du Front de libération des femmes (1969-1971) et du Centre des femmes (1972-1975) (Montréal: Les Éditions du remue-ménage, 1982), 25. As outlined in the 1990 report of the Rassemblement des femmes immigrantes du Québec, ethnic minorities in Québec, like elsewhere, reportedly experienced great difficulty integrating into mainstream feminist groups. See: Rassemblement des femmes immigrantes du Québec, Compte-rendu du rassemblement des femmes immigrantes $d u$ Québec (Montréal, Collectif des femmes immigrantes, 1990), 24. Furthermore, feminist publications such as La Vie en Rose were accused of containing articles on women in other countries, while overlooking women from these societies who actually lived in Montreal (See Ghila Sroka, Femmes Haïtiennes, Paroles de Négresses. Interviews de Ghila Sroka (Montréal: Les Editions de La Parole Métèque, 1995), 118. It was arguably not until 1992, with the event "Un Québec féminin au pluriel," that Francophone women explicitly included minority women in the quest for gender equality (Stasiulis, "Relational Positionalities of Nationalisms, 
Racisms, and Feminisms," 208.

61 Carmichael and Hamilton, Black Power: The Politics of Liberation in America, 2-6.

62 Robert Williams II, "From Anti-colonialism to Anti-apartheid: African American Political Organisations and African Liberation, 1957-93," in African Americans in Global Affairs: Contemporary Perspectives (Boston: Northeastern University Press, 2010), 69.

63 LAC, Dorothy Wills Fonds, MG 31 H179 Volume 7, File 7-9: Afrikan Liberation Day Message Delivered by "Abike" Dorothy Willis, Abike, "Statement to the Rally of the African Liberation Day, May 12 $2^{\text {th }}, 1972$," Dorothy Wills Fonds, MG 31 H179 Volume 7, File 7-9: Afrikan Liberation Day Message Delivered by "Abike" Dorothy Willis; Carmichael and Hamilton, Black Power: The Politics of Liberation in America, 9.

${ }^{64}$ Charles V. Hamilton, "Pan-Africanism and the Black Struggle in the U.S," The Black Scholar, March 1971, 10-15.

65 St. Clair Drake, "The Black Diaspora in Pan-African Perspective," The Black Scholar, September 1975, 2-13.

66 Rosemary Brown, Being Brown: A Very Public Life (Toronto: Random House, 1989), 32.

${ }^{67}$ LAC, Dorothy Wills Fonds, MG 31 H179 Volume 7, File 7-9: Afrikan Liberation Day Message Delivered by "Abike" Dorothy Wills “Address for African Liberation Day, Halifax, Nova Scotia, Saturday Morning -May 26 ${ }^{\text {th }}$, 1973."

68 Dawn P. Williams, "Rosemary Brown" in Black Success and Black Excellence in Canada: A Contemporary Directory (Toronto: D.P. Williams and Associates, 2002), 87; For examples of mistrust in the political system due to lack of numbers, see Larry Clark, “Letters," UHURU September 15 th 1969,2 or T.E. Merry, “The Political System and Minority Groups," Contrast, March 31'st, 1969, 14.

${ }^{69}$ Corrin, Cris, Feminist Perspectives on Politics (Edinburg: Pearson Education Limited, 1999), x; For more on a feminist approach to studying international relations, see Annick Wibben, "Feminist International Relations: Old Debates and New Directions," Brown Journal of World Affairs 10, no. 2 (Winter/Spring 2004): 97-114.

70 Roy-Campbell, Zaline Makini, "Pan-African Women Organising for the Future: The Formation of the Pan African Women's Liberation Organisation and Beyond," African Journal of Political Science New Series 1, no.1 (June 1996): 45$57,47$.

${ }^{71}$ LAC, Dorothy Wills Fonds, MG 31 H179 Volume 4, File 4-20: National Coalition of Canada Habari Kijiji (Village News) Newsletter edited by Dorothy Wills, "The Sixth Pan African Congress," Village News, September 1974.

72 LAC, Dorothy Wills Fonds, MG 31 H179 Volume 7, File 7-12: "Black 
Cultural Development" Keynote Address given by Dorothy Willis, Halifax, Nova Scotia. August 1974, Dorothy Wills, "Black Cultural Development," Keynote Address, Halifax 1974.

73 LAC, Dorothy Wills Fonds, MG 31 H179 Volume 7, File 7-9: Afrikan Liberation Day Message Delivered by "Abike" Dorothy Wills, "Statement to the Rally of the African Liberation Day, May 12, 1972 by Abike; Julius K. Nyerere, "African Socialism: Ujamaa in Practice," Black Scholar February 1971, 7.

74 Julius K. Nyerere, "African Socialism: Ujamaa in Practice," Black Scholar February 1971, 7. Julius Nyerere was Tanzania's first president and the visionary behind ujamaa.

75 LAC, Dorothy Wills Fonds, MG 31 H179 Volume 4, File 4-20: National Coalition of Canada Habari Kijiji (Village News) Newsletter edited by Dorothy Wills, “The NBCC as an Extended Family," Village News, March 1974.

76 LAC, Dorothy Wills Fonds, MG 31 H179 Volume 4, File 4-20: National Coalition of Canada Habari Kijiji (Village News) Newsletter edited by Dorothy Wills, "Quebec Board of Black Educators Workshop," Village News, April 1975. 77 LAC, Dorothy Wills Fonds, MG 31 H179 Volume 1, File 1-1: Dorothy Wills: Curriculum vitae, biographical information, and professional associations, "Curriculum Vitae."

78 LAC, Dorothy Wills Fonds, MG 31 H179 Volume 7, File 7-11: "Problems Facing Black Women in North American Society" Address given by Dorothy Willis to the "Think In" on Black Culture August 26-31, 1974, Cape Breton, Nova Scotia, "Think In" on Black Culture August 26-31 1974: Address on the Problems Facing Black Women in North American Society by Abike (Dorothy Wills)."

${ }^{79}$ LAC, Dorothy Wills Fonds, MG 31 H179 Volume 1, File 1-22: The Black Community Work Group in Education, "Final Report on the Aspirations and Expectations of the Quebec Black Community with regard to Education" Submitted by: The Black Community Work Group in Education to the: Comite d'etude sur les Affaires Interconfessionnelles et Interculturelles du Conseil superieur de l'Education, Montreal July 1978."

${ }^{80}$ LAC, Dorothy Wills Fonds, MG 31 H179 Volume 7, File 7-15: "The Cultural Differences of the Black Child in the Canadian School System," Dorothy Wills, "The Cultural Differences of the Black Child in the Canadian School System. Prepared for workshop discussion to be held at the P.S.B.G.M," May 2nd 1975. 81 LAC, Dorothy Wills Fonds, MG 31 H179 Volume 7, File 7-19: Addresses by Dorothy Willis delivered to Black Graduations and Community Dinners (19681975), Dorothy Wills, Speech "Rally 6pm George Brown College Toronto." 82 Imamy Ameer Baraka (LeRoi Jones), "A Black Value System," The Black Scholar, November 1969, 54-60.

83 Exploring the possibilities offered by Diaspora, Richard Iton criticizes the idea 
of the nation-state: "Toward this end, it might be argued that the nation itself, as a modern emergence, cannot sustain nonwhite aspirations for emancipation and that such projects require the decentring of the nation-state and the decoupling to colored subjectivities and the limiting framework of the national." In the same book, he also writes: "It is in the context that we think of diaspora as both mapping and contesting racial hierarchies, and as containing traces and suggesting potential ways of being beyond the extended problem spaces of coloniality and modernity." See Iton, In Search of Black Fantastic: Politics and Popular Culture in the Post-Civil Rights Era, 193, 203. There is a comparable literature criticizing the gendered nature of the nation-state. See, for example, Nira Yuval-Davis, "Women, Citizenship and Difference." Feminist Review 57 (autumn 1997): 4-27. ${ }^{84}$ For a study on the invisibility of African Canadian women in Canadian and Québécois history, see the work of community activist, lawyer, and Congress of Black Women member, Esmeralda Thornhill: Le revers de la médaille. Des oublis de l'bistoire Commission de droits de la personne du Québec. Montréal, le 13 juillet 1982, LAC, Dorothy Wills Fonds, MG 31 H179 Volume 6, File 6-18: Thornhill, Esmeralda: copies of her reports. 1982-1984.

85 LAC, Dorothy Wills Fonds, MG 31 H179 Volume 7, File 7-11: "Problems Facing Black Women in North American Society" Address given by Dorothy Wills to the "Think In" on Black Culture August 26-31, 1974. Cape Breton, Nova Scotia, "Think In" on Black Culture August 26-31 1974: Address on the Problems Facing Black Women in North American Society by Abike (Dorothy Wills)."

86 LAC, Dorothy Wills Fonds, MG 31 H179 Volume 4, File 4-20: National Coalition of Canada Habari Kijiji (Village News) Newsletter edited by Dorothy Wills, "The Sixth Pan African Congress," Village News, September 1974.

${ }^{87}$ LAC, Dorothy Wills Fonds, MG 31 H179 Volume 5, File 5-10: Pan African Congress (Azania) Project- Contributions for printing "Policy and Programme of the PAC of Azania, one of the liberation movement in South Africa, 1974,"

Dorothy Wills, Letter to the NBCC, September 14th 1974.

88 Dufoix, La dispersion: une histoire des usages du mot Diaspora, 264-265.

${ }^{89}$ Ibid.

90 LAC, Dorothy Wills Fonds, MG 31 H179 Volume 1, File 1-7: File of personal correspondence titled "The Struggle and Me," (1971-1979), Elias L. Ntloedible,

Letter to Dorothy Wills, Dar-Es-Salaam, November 21 ${ }^{\text {st }}, 1974$.

91 LAC, Dorothy Wills Fonds, MG 31 H179 Volume 1, File 1-7: File of personal correspondence titled “The Struggle and Me," (1971-1979), Okdt. Bernard R

Seme, Letter to Dorothy Wills, Dar-Es-Salaam, December 31 ${ }^{\text {st }}, 1975$.

92 Williams, The Road to Now, 52.

93 John Harewood, "NBCC Leaders: Bayne, Wills, Clarke," Contrast, October 
$24^{\text {th }}, 1975,6-7$.

94 LAC, Dorothy Wills Fonds, MG 31 H179 Volume 5, File 5-1: National Black Coalition of Canada "The National Black Awards of Canada," 1976 Forward by Abike (Dorothy Wills), Extract "Dorothy Wills: The Persistent Apostle of Identity, Unity, Liberation."

95 David Austin, "An Embarrassment of Omissions, or Rewriting the Sixties: The Case of the Caribbean Conference Committee, Canada, and the Global New Left," 370.

96 See, for example, Maulana Ron Karenga, "Which Road: Nationalism, PanAfricanism, or Socialism?," The Black Scholar, October 1974, 21-31.

97 See, for example, "Second Congress of Black Women," Village News, September 1974. There were similar articles in the October and December 1974 issues of Village News. See LAC, Dorothy Wills Fonds, MG 31 H179 Volume 4, File 4-20: National Coalition of Canada Habari Kijiji (Village News) Newsletter edited by Dorothy Wills.

98 LAC, Dorothy Wills Fonds, MG 31 H179 Volume 4, File 4-20: National Coalition of Canada Habari Kijiji (Village News) Newsletter edited by Dorothy Wills, "Second National Congress of Black Women a Tremendous Success," Village News, December 1974.

99 See Shirley Small and Esmeralda M.A. Thornhill, "Harambec! Quebec Black Women Pulling Together," Journal of Black Studies, 38, 3 (January 2008), 427-442. 100 Hazel V. Carby, "White Women listen! Black Feminism and the Boundaries of Sisterhood," in The Empire Strikes Back: Race and Racism in 70s Britain. Centre for Contemporary Cultural Studies, University of Birmingham (London:

Hutchinson and Co. Publishers Limited, 1982), 214.

101 LAC, Dorothy Wills Fonds MG 31 H179 Volume 9, File 9-23: Canadian Negro Women's Association -Report, The Canadian Negro Women's

Association, "Report of the First National Congress of Black Women April, $6^{\text {th }}$ $8^{\text {th }}, 1973$, Westbury Hotel, Toronto, Canada."

102 Jennifer Nelson, Women of Color and the Reproductive Rights Movement (New York: New York University Press, 2003), 2-4.

103 Dorothy Wills, "The status of the Black woman today," Contrast, September 13, $1972,14$.

104 LAC, Dorothy Wills Fonds, MG 31 H179 Volume 7, File 7-23: “The Status of the Black Woman in Today's World," by Dorothy Willis, Workshop Paper, Dorothy Wills, Workshop Paper entitled "The Status of the Black Women in Today's World."

105 Hazel V. Carby, "White Women listen! Black Feminism and the Boundaries of Sisterhood," 214. 
106 Karen Dubinsky, Babies without Borders: Adoption and Migration across the Americas (Toronto: University of Toronto Press, 2010), 72-73.

107 LAC, Dorothy Wills Fonds, MG 31 H179 Volume 9, File 9-23: Canadian Negro Women's Association -Report of the first National Congress of Black Women held April 6-8, 1973 Toronto, The Canadian Negro Women's Association, "Report of the First National Congress of Black Women April, $6^{\text {th }}$ $8^{\text {th }}, 1973$, Westbury Hotel, Toronto, Canada."

108 LAC, Dorothy Wills Fonds, MG 31 H179 Volume 7, File 7-23: “The Status of the Black Woman in Today's World” by Dorothy Willis, Workshop Paper, Dorothy Wills, "The Status of the Black Women in Today's World."

109 Frances Beal, "Double Jeopardy: To Be Black and Female," in The Black Woman: An Anthology, ed. Toni Cade (New York: New American Library, 1979), 90-100.

110 See Joella H. Gipson, PhD, ed. Impetus -The Black Woman: Proceedings of the Fourth National Congress of Black. Women of Canada (Windsor, Ontario, August 1921, 1977.) This document was located in Library and Archives Canada.

111 Paul Dejean, Les Haïtiens an Québec (Montréal : Les Presses de l'Université du Québec, 1978), 102.

112 Ibid.; LAC, Dorothy Wills Fonds, MG 31 H179 Volume 4, File 4-20:

National Coalition of Canada Habari Kijiji (Village News.) Newsletter edited by Dorothy Willis, Second National Congress of Black Women-Follow-up," Village News, January 1975.

113 The terminology of "dissident transnational citizenship" was taken from Chapter 8 of Daiva Stasiulis and Abigail Bakan, Negotiating Citizenship: Migrant Women in Canada and the Global System (New York: Palgrave Macmillan, 2003). 114“"Editorial: Fourth National Congress of Black Women," Contrast, August 25, 1977, 6 .

115 LAC, Dorothy Wills Fonds, MG 31 H179 Volume 9, File 9-23: Canadian Negro Women's Association - Report of the first National Congress of Black Women held April 6-8, 1973 Toronto, The Canadian Negro Women's

Association, "Report of the First National Congress of Black Women April, $6^{\text {th }}$ $8^{\text {th }}, 1973$, Westbury Hotel, Toronto, Canada."

116 Ibid.

117 Frances Beal, "Slave of a Slave No More: Black Women in Struggle," Black Scholar, March 1975, 2-10.

118 Brown, Being Brown, 80-84.

${ }^{119}$ For example, in an article published in The Black Scholar, Sekou Touré outlines the role of African women in the revolution. In spite of a few dubious claims, namely the absence of patriarchy in pre-conquest Africa, the first president of the independent Guinea asserted the mutually constitutive nature of two social 
movements, taking place all over the Black Diaspora: "If African women cannot possibly conduct their struggle in isolation from that our people wage for African liberation, African freedom, conversely, is not effective unless it brings about the liberation of African women." Sekou Touré, "The Role of Women in the Revolution," The Black Scholar, March 1975, 32-36. 